Гуров С.В.

\title{
Психологические особенности смыслообразования студентов: типы, стили, стратегии
}

На формирование смысловой сферы в юношеском возрасте оказывают влияние такие факторы, как: возраст, образование, профессиональное самоопределение. В зависимости от воздействия челого ряда факторов смысловая сфера личности в юношеском возрасте будет иметь различную степень сформированности, и это будет оказывать влияние на целеустремленность молодого человека, способность к целеполаганию и общую удовлетворенность жизнью. На современном этапе развития психологии выделяют различные типы, стили и стратегии смыслообразования, которые необходимо понимать как личностную готовность воспринимать содержание образования на ченностно смысловом уровне.

Ключвые слова: смысловая срера личности, смыслообразование, технол бал. инициации смыслообразования, типы, стили, стратегии.

В психолого-педагогических исследованиях, посвященных пр б- ие смыслообразования, можно выделить следующие основные напр Вле ил, которые рассматривают проблему смысловых инициаций в студенияском-зрасте:

-исследования проблемы выведения знаний на личносло-о ьїсловой уровень (В.В. Знаков, Ю.М. Шор, В.П. Зинченко);

-изучение вопроса о соотношении мотива и цели учебной деятельности (А.Н. Леонтьев и его последователи);

-изучение форм существования личност сысысла (Д.А. Леонтьев, В.Э. Мильман);

- исследование личностного смысла какпеғ аглического фактора (И.В. Абакумова, В.Т. Фоменко);

- разработка технологий направл Нно й опосредованной трансляции смыслов в учебном процессе (И.В. Аба ку, Ооа, Л.Ц. Кагермазова).

В многочисленных работа по ященных проблеме инициации смыслообразования (И.В. Абакумова, А.М Сиолов, Е.В. Клочко, В.Э. Мильман, М.С. Нырова, Е.Ю. Патяева) ставится о рос о необходимости разработать дидактические технологии, которые ак (длизируют смысловые процессы обучаемого. Это могут быть технологии беслечивающие самоактуализацию субъектного опыта учащихся и студент о (эм ционально-психологические установки и эмоциональнопсихологичє сял обобщения в обучении, эмоционально-психологическое опережение, ли 9н спо-смысловой контекст, преобразование теоретического материала в образнь; диалоговые технологии (внешний, внутренний, множественный диг 10 диалоги эпох, диалоги разнохарактерных культур); игровые технологии (ролезые и другие виды дидактических игр, включая компьютеры с их визуалисти4.кими возможностями); технологии, обеспечивающие самовыражение студентов 
(ситуации выбора, персонализация, задания на проявления саморефлексии, зоны экзистенциальных диалогов); технологии психолого-дидактической поддержки (ситуации успеха, зоны самодифференциации и самоиндивидуализации студентов, модели жизненного самоопределения, моделирование жизненных ситуаций и ситуаций поведения, метод личностно значимых конкретных ситуаций, метод инцидента, смысловое погружение).

Однако при разработке технологий инициации смыслообразования зачастую не учитывается, что у студентов, на которых направлена смысловая трансляция педагога, имеется различный смыслообразовательный потенциал. Сидящие в аудитории могут иметь чрезвычайно разную готовность к смысловой актуализации. От чего это зависит? Конечно, существует много личностных факторов, но мы хотели бы акцентировать внимание на процессах именно смысловой природы и провести дифференциацию тех смысловых характеристик, которые влияют на уровень потенциальной готовности личности к процессу смыслообра зования. В качестве таких характеристик можно взять типы, стили и стратеги и смыслообразования.

Типы смыслообразования - это особое состояние готовности к поисқусмысл б, сопровождающееся переживанием осмысленности жизни, личност о1 претацией человеком своей позиции относительно формировани ли. иилизни, своего места в обществе и способа жизни [7].

Т.В. Шрейбер предложила индикаторы, которые позволя. вы̆ыяить типы смыслообразования в старшем школьном и студенческоN Noзриятах:

-уровень осознанной саморегуляции, выступающий интеграяьным показателем сформированности основных регуляторных свойс в декватности и эффективности функционирования системы саморегуляци ии

-стиль саморегуляции, отражающий индивилуа юьо-типические особенности регуляции и реализации произвольной акт В гости;

-в качестве детерминант смыслообраз, मय и активности можно рассмотреть коммуникативную и интеллектуаль нУғ активность;

-мотивационные свойства - урояел гелей и уровень притязаний.

Эти индикаторы позволили вабить выявить различные типы смыслообразования:

-тип с одинаково вырауюн ой ориентацией на цель и процесс жизни;

-тип с доминирующей о бу =нтацией на процесс;

-тип с невыраженг й сысложизненной ориентацией.

Выделение тико. смь слообразования позволило обозначить их как высокий, средний и низк ау уровни смыслообразующей активности.

1. Респя नА ншы с высоким уровнем смыслообразующей активности ориентиров на общение, открыты, но в то же время властны, эмоционально 16. рйчивы, хорошо контролируют свои эмоции и поступки. Они отличаются Високой целеустремлённостью и высоким уровнем притязаний, имеют высокий социометрический статус и позитивно оценивают отношения 
в группе. Им присуща высокая интеллектуальная и психомоторная активность. Система осознанной саморегуляции высоко развита, отличается гармоничной сформированностью всех регуляторных звеньев.

2. Респонденты с низким уровнем смыслообразующей активности интровертированы, замкнуты, пассивны, оценивают психологический климат в группе как негативный. У них высокая тревожность и в то же время низкий уровень самоконтроля эмоций и поведения. Они независимы и в то же время у них отсутствуют определённые цели, которые стоило бы отстаивать. Их саморегуляция отличается малой адекватностью, гибкостью и осознанностью, а также несформированностью умения программировать собственные действия. То есть, смыслообразующая активность у них хаотична, ситуативна, малоосознаваема.

Наряду с исследованием типов смыслообразования, современная психо логическая наука (особенно ее акмеологическая составляющая) располагет характеристикой стилей смыслообразования, которые интерпретируютс, ка устойчивая система взаимодействия содержательно-смысловых и мотив ци рннодинамических составляющих в процессе самореализации личности-По мю Аию Д.В. Егорова, в различных профессиональных контекстах самореализ ии і различна, и можно выделить её устойчивые компоненты, которые проявля отся в олде общих и специфических характеристик содержательно-смысловой и мивационнодинамической сферы. К общим характеристикам относ.еслияливы обучения, толерантность в отношении к себе и другим, желание голдеривать физическое и психическое здоровье, независимость в суждениях и в-выборе собственной стратегии поведения, стремление к удовлетво еую от процесса обучения и дальнейшей трудовой деятельности. Специфи ме же характеристики самореализации различны в зависимости от личо тной направленности студентов. Особенности самореализации (а следоватлно и стиль смыслообразования) начинают формироваться на начальнь $39 \mathrm{~g}$ лах профессионального становления и становятся устойчивым личностн -сс ькловым конструктом у студентов на завершающем этапе их обучения в вух.для выявления стиля смыслообразования у студентов необходимо выдє и бщие и устойчивые компоненты самореализации, свойственные всем гт, пентам независимо от личностной направленности: мотивационные характақ тики, стремление к самоактуализации, ценностные ориентации и смыслож 3 ленные стратегии. Этот конструкт характеризуется достаточно высоким пуказателями осмысленности жизни и самоактуализации, включает любозь, здс حовье, наличие хороших и верных друзей, образованность, воспитанно ТР,независимость в качестве ведущих ценностей, среднюю степень выраженғо мм мотивации достижения и избегания неудач. Перечисленные характери ики позволяют выделить ряд общих факторов, характеризующих сти (ь) мыслообразования: «фактор мотивов учения», «фактор толерантности», «фактрр здоровья», «фактор независимости», «фактор интереса к работе и уче6., «фактор взаимоотношений». Для группы направленности на себя выделены 
факторы: «фактор критериев профессионализма», «фактор карьера - любовь», «фактор проявления жизненной мудрости в обучении», «фактор рисков обучения», «фактор шаблонности в притязаниях»; группе направленности на общение свойственны факторы: «фактор активной и разнообразной жизни», «учеба как самоцель», «средства достижения продуктивной жизни», «самоконтроль в общении», «пессимистическое отношение к трудоустройству»; в группе направленности на дело выделены: «фактор цели», «фактор постоянства деятельности», «фактор открытости», «фактор схожести», «фактор самоконтроля».

Еще одна типология характеристик смыслообразования связана с выделением смысложизненных стратегий. В зависимости от воздействия внешних факторов смысловая сфера личности в юношеском возрасте будет иметь различную степень сформированности, что будет оказывать влияние на целеустремленность молодого человека, способность к целеполаганию и общую удовлетворенность жизнью. Именно на этом этапе формируются смысложизненные стратегии - «устой чивая система личностных смыслов индивида, позволяющая оптимизирова ь или минимизировать активность субъекта во взаимоотношениях с объект ВР ри действительностью и проявляющаяся в отношении к цели, процессу и пезульт деятельности, а также в отношении к жизни и самому себе» [1]. Смысло, ки-Fеныные стратегии проявляют себя в трех сферах: в отношении к самому бе, в-1ношении других людей, требования к социуму в целом. В каждой из тре. $е$ ер могут формироваться соответствующие личностные проявления, көтру еудут носить достаточно устойчивый характер.

Смысложизненная стратегия представляет собой частнын случай более глобального, интегрального образования - смысложизн гяй концепции личности. Можно сказать, что смысложизненная стратегия пр Оавляет собой динамическую проекцию смысложизненной концепции пи ности на конкретные условия ее повседневной жизни.

Т.В. Столина дает следующее опреде, яие смысложизненной концепции «это, индивидуальная обобщенная сис ем. Взглядов на цели, процесс и результат своей жизни. В основе этой концеп! ии тетат ценности и потребности, отношения и конструкты конкретной личнос и. . осложизненная концепция начинает складываться к подростковому в зे асту, иожет изменяться и трансформироваться на протяжении жизни челяе $э$, но на определенном этапе онтогенеза является достаточно устойчивой» [5. Т.ким образом, можно сказать, что смысложизненная концепция - это стер, Не ая направленность личности, ее смысл жизни. Она содержит в себе те жми нен, ые смысловые универсалии, те ценности, которые и составляют основ Ричности.

Механиз ориирования смысложизненных стратегий определяется рядом факторов: о -бенностями мотивационно-интенциальной сферы, хронологическим ғз. астом, жизненным контекстом, социокультурными и экономическими условия Модель формирования смысложизненной стратегии исходя из вышеер численных посылок, может быть интерпретирована следующим образом. 
Смысловые стратегии - динамическая составляющая смысловой сферы. Они предстают смысловыми новообразованиями личности, изменяющими всю смысловую структуру.

Стремление описать динамику формирования смысловой сферы через достаточно устойчивые стратегии, породило стремление к упорядоченности, естественному желанию расположить смыслы в системном порядке в зависимости от специфики смысловых образований личности. Наиболее очевидным предстает диадная природа смысла, его континуумная динамика от минимального к максимальному насыщению: от становящегося смысла - к ставшему, от неопределенного смысла - к определенному (в рамках ценностного отношения), от постигаемого смысла - к постигнутому. При таком подходе просматривается закономерная последовательность как интегральная динамическая характеристика индивидуального сознания обнаруживается в последовательности «от смыслового сле да - к категориальному обозначению смысла в его явленном виде» и, собствешн, соответствует той логике процесса смыслообразования, которая выявляется тами как устойчивая смысловая направленность т.е. смысловая стратегия.

Выделенные и описанные типы, стили и стратегии смыслообразовани позволяют придать учебному процессу направленный характер. П еро пав̈атель, ориентируясь в смысловом потенциале студентов, значителью блес успешно сможет актуализировать смыслообразование студентов.

\section{Литература}

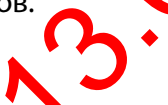

1. Абакумова И.В. Обучение и смысл: смыслообразование в учебном процессе. Психолого-дидактический подход. - Ростов-на Ду чу: Изд-во РГУ, 2003. - 480 с.

2. Егоров Д.В. Психологические компоненты Сь Юовой самореализации студентов психологов в контексте различних юофессиональных перспектив // Российский психологический журнал, 2097. - Т. 4. - № 1. - С. 38-40.

3. Левшина А.А. Молодежь в политике. Пرвационно-смысловая основа участия молодежи в общественно-пол Ти еских организациях // Saarbrücken LAP LAMBERT Academic Publishin O \& \& Co. KG., 2011. - P. 1-74

4. Столин В.В. Проблема самq о مия личности с позиции теории деятельности А.Н. Леонтьева // А.Н. Лго, лев и современная психология / под ред. А.В. Запорожца и др. - М.: ИзпвоМГУ, 1983. - С. 220-231.

5. Столина Т.В.Смыспон 13 генная концепция и агрессивность учащихся-подростков: автореф. дис., ка д. психол. наук. - СПб., 2002. - 20 с.

6. Шрейбер Тю. Осо зенности саморегуляции старшеклассников с различным уровнем олмысленности жизни // Вестник Удмуртского университета. Психология им едагогика. - 2005. - № 9. - С. 63-78.

7. Шрей Т. Т. Проблема регуляции смыслообразующей активности в раннем 아 шеском возрасте // Реалии и перспективы психологической науки и практики В оссийском обществе: материалы Всероссийской научно-практ. конф. - Најережные Челны: Изд-во Института управления, 2005. - С. 80-83. 